\title{
COMBINING ABILITY FOR GROWTH, YIELD AND RELATED TRAITS IN CUCUMBER (CUCUMIS SATIVUS L.) UNDER SUBTROPICAL CONDITIONS OF GARHWAL HIMALAYAS
}

\author{
KN ShaH, DK RaNa AND V SINGH* \\ Department of Horticulture, HNB Garhwal University, Srinagar, \\ Garhwal, Uttarakhand, 246174, India \\ Keywords: Diallel, General, Specific, Combining ability, Cucumber
}

\begin{abstract}
To assess the combining ability for quantitative and qualitative traits in cucumber a full diallel set of 7 parents and their $42 \mathrm{~F}_{1}$ 's was evaluated at Horticultural Research Centre, Department of Horticulture, H.N.B. Garhwal University, Srinagar (Garhwal), Uttarakhand, India during 2015 and 2016. The mean sum of squares due to general combining ability (GCA) was of significant differences at $1 \%$ level for almost all the characters. The variance due to specific combining ability (SCA) was found highly significant at $1 \%$ level for almost all the characters. Results from general combining ability studies revealed that the parent, New Manipur-1 showed significant GCA effect in desired direction for maximum characters viz., length of vine, days to first fruit harvest and number of fruits per vine. The cross combinations, Seven Star x New Manipur-1 for length of vine, Swarna Purna x Seven Star for days to first fruit harvest; K-90 x Seven Star for number of fruits per vine and the cross PB-Naveen x Swarna Purna for total fruit yield per vine showed significant SCA effect in desired direction and found to be superior specific cross combinations.
\end{abstract}

\section{Introduction}

Among the cucurbitaceous vegetable's crops, cucumber (Cucumis sativus L.) is most valuable and commercially cultivated all over the world especially in tropical and sub-tropical climatic conditions. It is a major salad crop grown in summer season, the edible tender fruits are also used as pickled, boiled, juice, snacks and cooked vegetable (Shah et al. 2016). It is an ideal summer vegetable crop chiefly grown for its edible tender fruits. Cucumber juice is still useful for treating diseases of teeth and gums, rheumatic conditions and healthy growing hair (Khulakpam et al. 2015).

For the production of any hybrids, two key factors are involved i.e., general and specific combining ability. Estimation of combining ability can be used to determine the usefulness of the inbred lines in hybrid combinations (Machikowa et al. 2011). The general combining ability (GCA) helps in selection of superior parents whereas specific combining ability (SCA) determines the selection of superior hybrids. These two types of combining abilities reflect different types of interactions between alleles at the gene loci. GCA and SCA involved in the expression of additive gene action and dominances and epistatic gene action, respectively. However, SCA contributed in large part of the dominance gene action. The information generated in the process is helpful to understand the magnitude of heterosis in $F_{1}$ hybrids. The merits of diallel analysis in plant breeding have been hotly debated but it remains a popular technique for combining a detailed genetic analysis of a small fixed set of genotypes (usually commercial cultivars) with the production of the hybrid seed for further breeding work. The diallel analysis (Matizinger et al. 1959) is useful to estimate the combining ability (general and specific combining ability) of the parents. Further, the diallel mating design provides an opportunity to mate the given set of parents in all possible combinations (Griffing 1956) and it provides information on combining ability and

\footnotetext{
*Author for correspondence: <bibek007singh@gmail.com>.
} 
thus helps in the selection of desirable parents for utilization in the hybridization programme, as well as in the choice of appropriate breeding procedure for the genetic improvement of various quantitative traits in the crop species. To tide over the situation, there is a need to make intensive efforts to develop site specific hybrids having desirable horticultural and quality traits, and to make available their seeds to the farmers at a reasonable price. Keeping in view the economic importance and above discussed facts, there is a need for improving and evaluating the quantitative and qualitative traits of cucumber under hill condition. Therefore, the present investigation was undertaken to determine the extent of combining ability for quantitative and qualitative parameters in cucumber.

\section{Materials and Methods}

Seven genotypes of cucumber namely, K-90, New Manipur-1, New Manipur-2, PB-Naveen, Seven Star, SPP-63 and Swarna Purna were crossed in all possible combinations including reciprocal crosses during the year 2015 using full diallel mating design suggested by Griffing (1956) to develop $42 \mathrm{~F}_{1}{ }_{1} \mathrm{~s}$ hybrids. During the year 2016, seven parents with their $42 \mathrm{~F}_{1}{ }_{1} \mathrm{~s}$ hybrids were evaluated for estimating the combining ability in respect of various characters at Horticultural Research Centre, Department of Horticulture, H.N.B. Garhwal University, Srinagar (Garhwal), Uttarakhand. The experiment was carried out in randomized block design with three replications. The research plot was divided into three blocks of equal size and each block possessed 7 beds during the year 2015 and 49 beds during the year 2016 of equal size $(4.50 \times 2.0$ $\mathrm{m})$. The seedlings were transplanted at four leaf stages at a spacing of $1.50 \times 0.50 \mathrm{~m}$. All the intercultural operations and plant protection measures recommended for the successful crop growth were followed during the investigation. Five plants were randomly selected and tagged from each treatment per replication for recording the following data viz., days to first seed germination, germination rate, length of vine $(\mathrm{cm})$, number of primary branches per vine, number of nodes per vine, days taken to opening of first male flower, days taken to opening of first female flower, number of nodes bearing first male flower, number of nodes bearing first female flower, fruit setting (\%), days to first fruit harvest, fruits/vine, total fruit yield/vine $(\mathrm{kg})$, fruit length $(\mathrm{cm})$, weight of fruit $(\mathrm{g})$, diameter of fruit $(\mathrm{cm})$, duration of harvesting (days), vitamin $\mathrm{C}(\mathrm{mg} / 100 \mathrm{~g})$ (Ranganna 2004), total soluble solids ( ${ }^{\circ}$ Brix) and number of seeds per fruit. Vitamin D was estimated by the procedure given by Diallel and combining ability analysis [(Griffing 1956). Model I (fixed), Method 1] was carried out that involved the parents, $F_{1}$ of both direct and reciprocal crosses.

\section{Results and Discussion}

Analysis of variance for combining ability in respect of growth, yield and quality characters is presented in Table 1. The mean sum of squares due to GCA was significantly different at $1 \%$ level for almost all the characters, while germination rate showed non-significant difference. The variance due to SCA was found to be highly significant at $1 \%$ level for almost all the characters, while germination rate and diameter of fruit exhibited significant difference at $5 \%$ level. The mean sum of squares due to reciprocal was observed highly significant at $1 \%$ level for all the characters. This result indicates that, the expression of almost all the characters is due to join effect of additive as well as non-additive genes. Improvement for all these traits in the materials studied can be achieved by few cycles of recurrent selection (Niyaria and Bhalala 2001).

Results from general combining ability studies presented in Table 2 revealed that the parent, New Manipur-1 showed significant GCA effect in desired direction for maximum characters viz, length of vine $(14.45 \mathrm{~cm})$, number of nodes per vine (4.35), days to first fruit harvest (1.28), number of fruits per vine (2.59), total fruit yield per vine $(0.41 \mathrm{~kg})$, weight per fruit $(10.98 \mathrm{~g})$, 
diameter per fruit $(0.43 \mathrm{~cm})$ and duration of harvesting (7.68 days). The parent New Manipur-2 showed significant GCA effect for days to first seed germination $(-0.28)$, per cent of fruit setting (4.39), TSS (0.95) and number of seeds per fruit (28.84). The parent PB-Naveen showed significant GCA effect for number of nodes bearing first male and female flower and length of fruit. Days taken to opening of first male and female flower and vitamin $\mathrm{C}$ showed significant GCA effect in the parent Swarna Purna which corroborate with the results reported by Kumara et al. (2011), Verma et al. (2013) in bitter gourd, Mule et al. (2011) and Singh et al. (2011) in cucumber and Shinde et al. (2016) in bottle gourd. Therefore, the parents New Manipur-1, New Manipur-2, PB-Naveen and Swarna Purna would be considered as best general combiners as they showed good general combiner for maximum traits in this study.

Table 1. Analysis of variance of combining ability for growth, yield and quality parameters in cucumber.

\begin{tabular}{|c|c|c|c|c|}
\hline \multirow{2}{*}{$\begin{array}{l}\text { Source } \\
\text { Degree of freedom }\end{array}$} & \multicolumn{4}{|c|}{ Mean sum of square } \\
\hline & GCA 6 & SCA 21 & Reciprocal 21 & Error 96 \\
\hline Days to first seed germination & $0.669 * *$ & $0.163 * *$ & $0.300 * *$ & 0.034 \\
\hline Germination rate & 0.048 & $0.052 *$ & $0.087 * *$ & 0.031 \\
\hline Length of vine (cm) & $847.60 * *$ & $44.78 * *$ & $100.58 * *$ & 0.045 \\
\hline Number of primary branches per vine & $2.831 * *$ & $0.177 * *$ & $0.214 * *$ & 0.029 \\
\hline Number of nodes per vine & $64.814 * *$ & $20.083 * *$ & $24.313 * *$ & 0.073 \\
\hline Days taken to opening of first male flower & $11.047 * *$ & $2.050 * *$ & $5.228 * *$ & 0.106 \\
\hline Number of nodes bearing first male flower & $2.782 * *$ & $0.128 * *$ & $0.238 * *$ & 0.043 \\
\hline Days taken to opening first female flower & $16.648 * *$ & $2.842 * *$ & $4.817 * *$ & 0.100 \\
\hline Number of nodes bearing first female flower & $3.245^{* *}$ & $0.347 * *$ & $0.455^{* *}$ & 0.031 \\
\hline Percent of fruit setting & $137.50 * *$ & $9.115^{* *}$ & $7.358 * *$ & 0.062 \\
\hline Days to first fruit harvest & $18.197 * *$ & $18.586^{* *}$ & $12.167 * *$ & 0.063 \\
\hline Number of fruits per vine & $27.055^{* *}$ & $1.453 * *$ & $1.951 * *$ & 0.112 \\
\hline Total fruit yield per vine $(\mathrm{kg})$ & $1.043 * *$ & $0.141 * *$ & $0.133 * *$ & 0.056 \\
\hline Length of fruit $(\mathrm{cm})$ & $25.609 * *$ & $1.513 * *$ & $1.302 * *$ & 0.063 \\
\hline Weight of fruit (g) & $750.31 * *$ & $25.759 * *$ & $63.783 * *$ & 0.086 \\
\hline Diameter of fruit (cm) & $1.874 * *$ & $0.054 *$ & $0.191 * *$ & 0.029 \\
\hline Duration of harvesting (days) & $17.896 * *$ & $19.986 * *$ & $12.640 * *$ & 0.088 \\
\hline Vitamin C (mg/100g) & $1.686^{* *}$ & $0.209 * *$ & $0.099 * *$ & 0.043 \\
\hline Total Soluble Solids $\left({ }^{\circ}\right.$ Brix $)$ & $5.223 * *$ & $0.292 * *$ & $0.377 * *$ & 0.054 \\
\hline Number of seeds per fruit & $4778.58 * *$ & $351.723 * *$ & $692.842 * *$ & 0.102 \\
\hline
\end{tabular}

*Significant at $5 \%$ level. **Significant at $1 \%$ level.

The specific combining ability is the result of non-additive gene action and is not fixable in segregating generations. Results presented in Table 3 reveals that, the cross combinations; Seven Star $\times$ New Manipur-1 for length of vine $(9.10 \mathrm{~cm})$ and weight of fruit $(5.59 \mathrm{~g})$; PB-Naveen $\times$ SPP-63 for number of primary branches per vine $(0.58)$; K-90 $\times$ SPP-63 for days taken to opening of first female flower (-1.64) and number of seeds per fruit (36.55); New Manipur-1 $\times$ New Manipur 2 for per cent of fruit setting (4.90); Swarna Purna x Seven Star for days to first fruit harvest (-5.90); K-90 x Seven Star for number of fruits per vine (1.41); the cross PB-Naveen $\times$ Swarna Purna for total fruit yield per vine $(0.55 \mathrm{~kg})$; the cross PB-Naveen $\times$ New Manipur- 2 for number of nodes bearing first female flower $(-0.57)$ and TSS $(0.71)$; the cross SPP- $63 \times$ New Manipur-1 for germination rate $(0.36)$ and fruit length $(1.48 \mathrm{~cm})$; the cross K- $90 \times$ Swarna Purna 


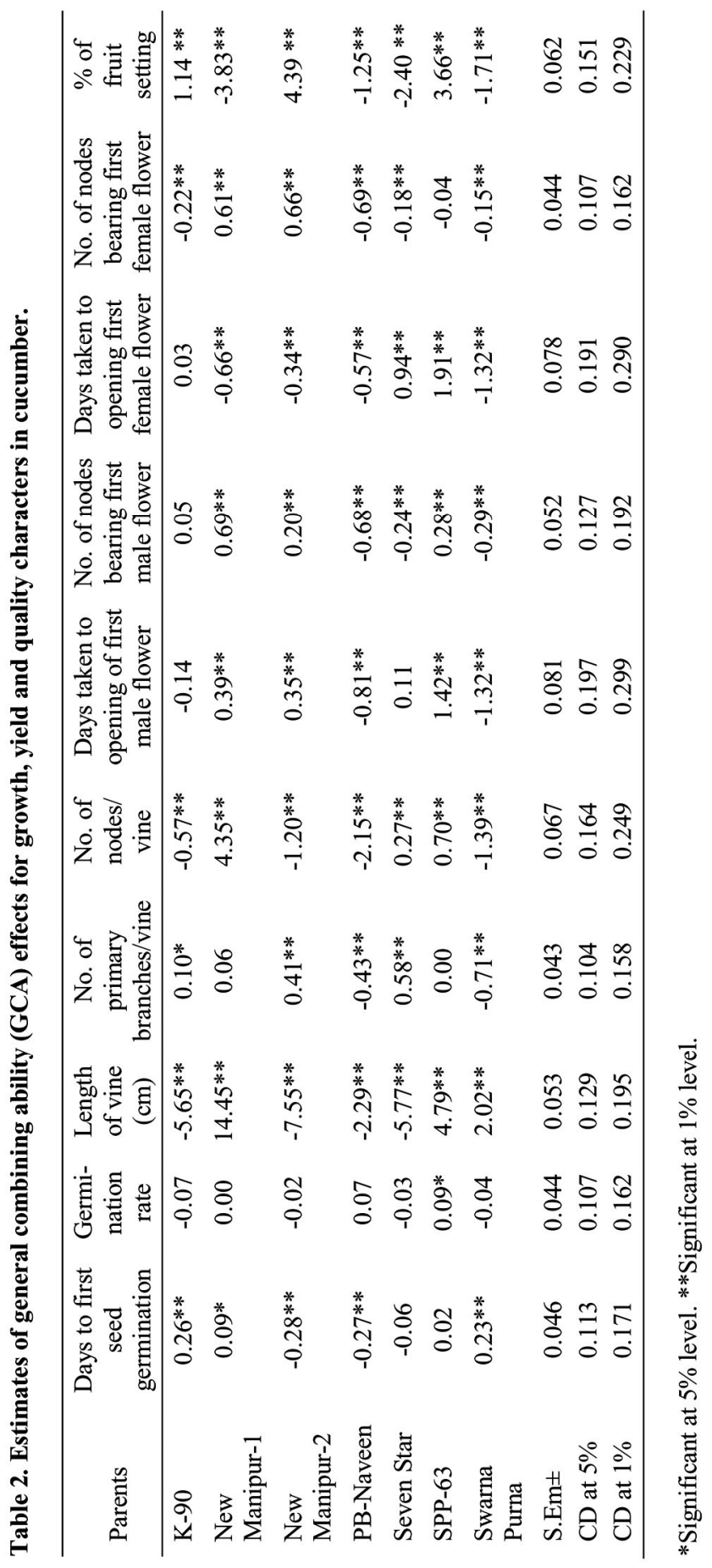




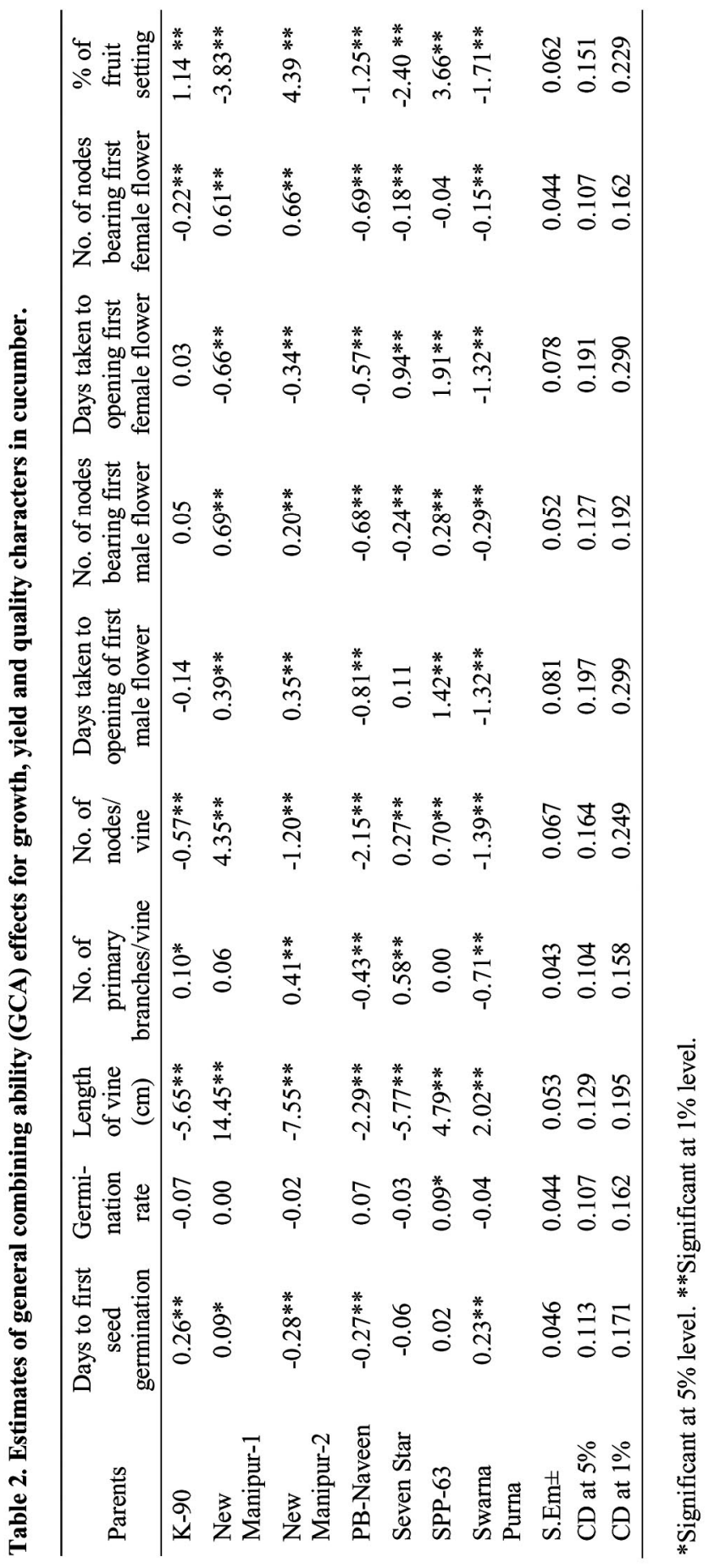




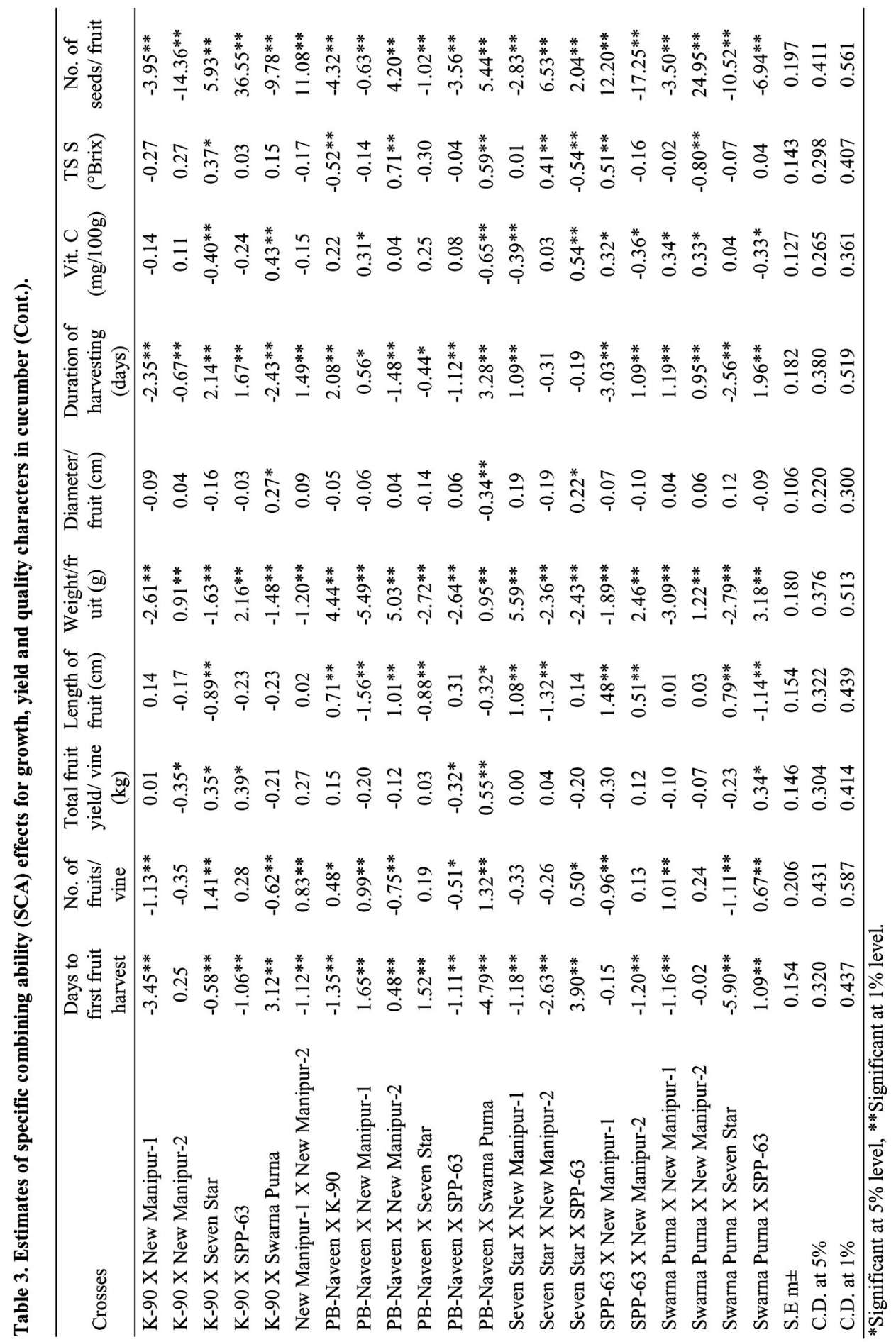


for fruit diameter $(0.27 \mathrm{~cm})$ and the cross Seven Star $\times$ SPP-63 for Vitamin C $(0.54 \mathrm{mg} / 100 \mathrm{~g})$ showed significant SCA effect in desired direction and found to be superior specific cross combinations in the present study. Previously the similar results were also observed (Kumara et al. 2011, Verma et al. 2013) in bitter gourd, (Selvi et al. 2015) in pumpkin, (Shaikh et al. 2011) in bottle gourd, (Naliyadhara et al. 2010) in sponge gourd and (Mule et al. 2011) in cucumber.

From the above findings, it may be concluded that the cucumber genotypes New Manipur-1 and New Manipur-2 proved as best general combiner and could be utilized in several crossing programme to develop high yielding cucumber genotypes. The crosses viz., S even Star $\times$ New Manipur-1, PB-Naveen $\times$ New Manipur-2, PB-Naveen $\times$ SPP-63, K-90 $\times$ SPP-63, New Manipur-1 $\times$ New Manipur 2, K-90 $\times$ Seven Star, PB-Naveen $\times$ Swarna Purna, SPP-63 $\times$ New Manipur-1 had at least one good general combiner parent and had high SCA effect suggesting heterosis breeding as a suitable strategy for the improvement of vigorous high yielding genotypes from the succeeding progenies.

\section{References}

Griffing B 1956. Concepts of general and specific combining ability in relation to diallel crossing systems. Aus. J. Bio. Sci. 9: 463-493.

Khulakpam NS, Singh V and Rana DK 2015. Medicinal importance of cucurbitaceous Crops. Int. Res. J. Bio. Sci. 4(6): 1-3.

Kumara BS, Puttaraju TB, Hongal S, Prakash K, Jainag K and Sudheesh NK 2011. Combining ability studies in bitter gourd (Momordica charantia L.) for quantitative characters. Asian J. Hort. 6(1): 135-140.

Machikowa T, Saetang C and Funpeng K 2011. General and specific combining ability for quantitative characters in sunflower. J. Agri. Sci. 3(1), 91-95.

Matzinger DF, Spraque GF and Cockerham CC 1959. Diallel crosses of maize in experiments repeated over locations and years. Agron. J. 51: 346-350.

Mule PN, Khandehwal V, Patil AB and Chaudhary BR 2011. Combining ability studies in cucumber (Cucumis sativus L.). Veg. Sci. 38(2): 203-205.

Naliyadhara MV, Dhaduk LK, Barad AV and Mehta DR 2010. Combining ability analysis in sponge gourd (Luffa cylindrica). Veg. Sci. 37(1): 21-24.

Niyaria R and Bhalala MK 2001. Heterosis and combining ability in ridge gourd. Indian J. Plant Gen. Res. 14:101-102.

Ranganna S 2004. Handbook of Analysis and Quality Control for Fruits and Vegetable Products (2nd Ed). McGraw Hill Education (India) Private Limited, New Delhi. pp. 105-126.

Selvi NAT, Jansirani P and Pugalendhi L 2015. Line x tester analysis for yield and its component traits in pumpkin (Cucurbita moschata Duch. Ex Poir). Elec. J. Plant Bree. 6(4): 1004-1010.

Shah KN, Rana DK and Singh V 2016. Evaluation of different cucumber strain for various horticultural traits under valley condition of Garhwal Himalaya. J. Plant Dev. Sci. 8(12): 599-603.

Shaikh JA, Kathiria KB and Acharya RR 2011. Heterosis and combining ability for fruit yield and its component traits in bottle gourd [Lagenaria siceraria (Mol.) Standl.] Veg. Sci. 38(2): 169-175.

Shinde S, Supe VS, Bhalekar MN and Gaikwad SS 2016. Combining ability studies for earliness and yield in bottle gourd (Lagenararia siceraria Mol. Standl.) in kharif season. Asian J. Sci. Tech. 7(2): 2846-2849.

Singh R, Singh AK, Kumar S, Singh BK and Singh SP 2011. Combining ability studies in cucumber (Cucumis sativus L.). Veg. Sci. 38(1): 49-52.

Verma RS, Pratap N, Dubey DK and Singh SS 2013. Combining ability and gene action indigenous bitter gourd (Momordica charantia L.). SAARC J. Agri. 11(2): 117-127.

Wright AJ 1985. Diallel designs, analysis and reference populations. Heredity 54: 307-311. 